\title{
HUBUNGAN ANTARA SELF EFFICACY DAN KREATIVITAS DENGAN MINAT BERWIRAUSAHA
}

\author{
Rifqi Hapsah dan Siti Ina Savira \\ Program Studi Psikologi Universitas Negeri Surabaya
}

\begin{abstract}
The purpose of this research is to examine the correlation between self efficacy and interest in entrepreneurship, the correlation between creativity and interest in entrepreneurship and, the correleation between self efficacy and creativity with interest in entrepreneurship. This research used quantitative approach with correlation method. Scales of self efficacy, creativity and entrepreneurship were given to 82 college students of School of Psychology from four different years who were selected using random technique sampling. This research applies 5\% significant level. The data were analyzed using product moment, and multiple-correlation test. The significant value from correlation between self-efficacy and interest in entrepreneurship is 0,000, with correlation index of 0.703, which means that there is a significant relationship between self-efficacy and interest in entrepreneurship. The significant value from correlation between creativity and interest in entrepreneurship is 0,008, with correlation index of 0.292 . It can be concluded that there is a significant relationship between creativity and interest in entrepreneurship. The result of multiple-correlation test shows correlation coefficient between self efficacy and creativity with entrepreneurship as much as 0,757 and Fh $(57,2)>$ Ftabel $(3,112)$. Therefore, it can be concluded that there is a significant correlation between self efficacy and creativity with interest in entrepreneurship.
\end{abstract}

Keywords : Self Efficacy, Creativity, Interest in Entrepreneurship

\begin{abstract}
Abstrak: Penelitian ini bertujuan untuk mengetahui hubungan self efficaccy dengan minat berwirausaha, hubungan kreativitas dengan minat berwirausaha, dan hubungan self efficaccy dan kreativitas dengan minat berwirausaha. Penelitian ini menggunakan pendekatan kuantitatif dengan metode korelasional. Skala self efficacy, skala kreativitas, dan skala minat berwirausaha diberikan kepada 82 subjek penelitian, yaitu mahasiswa Psikologi dari 4 angkatan yang dipilih dengan teknik random sampling. Peneliti menggunakan taraf kesalahan 5\% dan metode analisis data korelasi product moment dan uji korelasi ganda. Analisis data menunjukkan terdapat hubungan signifikan antara self efficacy dengan minat berwirausaha sebesar 0,000, dengan indeks korelasi sebesar 0,703. Terdapat hubungan yang signifikan pula antara kreativitas dengan minat berwirausaha sebesar 0,008, dengan indeks korelasi sebesar 0,292. Hasil uji korelasi ganda menunjukkan koefisien korelasi antara self efficacy dan kreativitas dengan minat berwirausaha sebesar 0,757, dan Fh $(57,2)>$ Ftabel $(3,112)$, sehingga dapat disimpulkan bahwa ada hubungan yang signifikan antara self efficacy dan kreativitas dengan minat berwirausaha.
\end{abstract}

Kata Kunci: Self Efficacy, Kreativitas, Minat Berwirausaha

Sejalan dengan terintegrasinya perekonomian ditengah era globalisasi, maka setiap permasalahan ekonomi di dunia akan saling mempengaruhi dalam berbagai pihak. Dinamika perekonomian Indonesia tidak terlepas dari perkembangan ekonomi global. Indonesia sebagai negara yang sedang berkembang harus mampu bersaing dalam persaingan ekonomi dunia. Berikut data pertumbuhan ekonomi Indonesia.

Korespondensi tentang artikel ini dapat dialamatkan kepada Rifqi Hapsah melalui e-mail: rifqireef@gmail.com 
Tabel 1. Data Pertumbuhan Ekonomi Indonesia

\begin{tabular}{lllll}
\hline Indikator & $\mathbf{2 0 0 6}$ & $\mathbf{2 0 0 7}$ & $\mathbf{2 0 0 8}$ & $\mathbf{2 0 0 9}$ \\
\hline Pertumbuhan Ekonomi (\%) & 5,5 & 6,28 & 6,06 & 4,5 \\
\hline Inflasi (\%) & 6,6 & 6,59 & 11,39 & 2,8 \\
\hline $\begin{array}{l}\text { NIlai ekspor non migas } \\
\text { (ribuan USD) }\end{array}$ & 80.091 .764 & 92.598 .083 & 107.156 .801 & $4.3991 .772^{*}$ \\
\hline FDI (juta USD) & 4.914 & 6.928 & n.a. & 4.877 \\
\hline Rupiah/USD & 9.020 & 9.419 & 10.950 & 10.87 \\
\hline
\end{tabular}

*s.d. Juli 2009

BPS (2010), Bank Indonesia (2010), diolah.

Sejalan dengan terintegrasinya perekonomian ditengah era globalisasi, maka setiap permasalahan ekonomi di dunia akan saling mempengaruhi dalam berbagai pihak. Dinamika perekonomian Indonesia tidak terlepas dari perkembangan ekonomi global. Indonesia sebagai negara yang sedang berkembang harus mampu bersaing dalam persaingan ekonomi dunia. Berikut data pertumbuhan ekonomi Indonesia.

Berdasarkan data pertumbuhan ekomomi Indonesia pada tahun 20062009 terjadi penurunan dari $6,28 \%$ menjadi $4,5 \%$. Tingkat perekonomian ini memiliki pengaruh pada kegiatan ekomoni Indonesia namun masih dalam kondisi relatif stabil. Pada tahun 2012 angka pertumbuhan ekomoni Indonesia berada pada $6,2 \%$ dengan perkiraan akan lebih meningkat lagi pada tahun 2013 (Bank Indonesia:2013). Kondisi pertumbuhan ekonomi tersebut tentunya akan mempengaruhi berbagai aspek kehidupan masyarakat mulai dari harga kebutuhan pokok, pendidikan, keamanan, ketersediaan lapangan kerja dan lain sebagainya.

Tingginya jumlah pengangguran menunjukkan sempitnya lapangan pekerjaan. Masyarakat Indonesia saat ini mengeluhkan sempitnya lapangan kerja dan wirausaha merupakan solusi yang dapat dijadikan jalan keluar. Berikut data pengangguran menurut Badan Pusat Statistik Indonesia mengenai tingkat Pengangguran Terbuka (TPT) dintinjau dari pendidikan tertinggi yang ditamatkan 2011-2012 (persen).

Tabel 2. Data Pengangguran Menurut BPSI dalam Persen (\%)

\begin{tabular}{lllll}
\hline $\begin{array}{l}\text { Pendidikan yang } \\
\text { ditamatkan }\end{array}$ & \multicolumn{2}{c}{$\mathbf{2 0 1 1}$} & $\mathbf{2 0 1 2}$ & \\
\cline { 2 - 5 } & Februari & Agustus & Februari & Agustus \\
\hline SD ke bawah & 3,37 & 3,56 & 3,69 & 3,64 \\
\hline $\begin{array}{l}\text { Sekolah } \\
\text { Menengah }\end{array}$ & 7,83 & 8,37 & 7,80 & 7,76 \\
Pertama & & & & \\
\hline Sekolah & 12,17 & 10,66 & 10,34 & 9,60 \\
Menengah Atas & & & & \\
\hline Sekolah & 10,00 & 10,43 & 9,51 & 9,87 \\
Menengah & & & & \\
Kejuruan & 11,59 & 7,16 & 7,50 & 6,21 \\
\hline $\begin{array}{l}\text { Diploma I/II/III } \\
\text { Universitas }\end{array}$ & 9,95 & 8,02 & 6,95 & 5,91 \\
\hline Jumlah & 6,80 & 6,56 & 6,32 & 6,14 \\
\hline (Badan Pusat Statistik:2013) & & \\
\hline
\end{tabular}

(Badan Pusat Statistik:2013)

Angka pengangguran ini cukup tinggi jika dikalikan dengan jumlah penduduk Indonesia yang sangat besar. Jika angka pengangguran ini bisa diubah menjadi untuk menjadi jumlah wirausaha maka perekonomian negara akan menjadi sangat kuat karena pada dasarnya setiap orang memiliki peluang untuk berwirausaha. Peluang-peluang lapangan kerja juga semakin bermunculan seiring berkembangnya wirausaha sehingga pengangguran semakin berkurang.

Menurut Rumawouw (2010), bahwa kehadiran wirausaha dapat membantu petumbuhan ekonomi suatu negara dan dengan memaksimalkan potensi wirausaha 
maka akan memperkuat perekonomian karena dalam proses wirausaha menciptakan nilai tambah dan pengembangan dalam berbagai aspek. Muncul dan berkembangnya wirausaha juga akan mengembangkan lapangan kerja untuk masyarakat.

Menurut data Badan Pusat Statistik jumlah wirausaha pada Februari 2013 mencapai 42,55 juta orang. Semakin besar jumlah wirausaha maka akan menjadi enterpreneurial engine bagi perekonomian nasional (Hadisoegondo, 2006).

Semboyan SMK siap mencetak tenaga kerja ahli, salah satunya sekolah vokasi yang sedang dikembangkan UGM (Universitas Gajah Mada) dengan tujuan mencetak lulusan siap kerja. Kalimat seperti ini menunjukkan bahwa sekolah hanya mendidik seseorang untuk menjadi seorang karyawan. Jumlah karyawan yang semakin bertambah sedangkan jumlah lapangan pekerjaan tidak ditambah, sehingga angka pengangguran semakin meningkat. Pengembangan minat terhadap wirausaha dirasakan belum maksimal terlihat seperti masih adanya pandangan untuk apa sekolah tinggi jika hanya ingin jadi pedagang (Alma, 2011). Sekolah pada tingkat yang lebih tinggi mengajarkan individu untuk dapat berpikir pada tingkat yang lebih tinggi. Tingkat kompetensi antara mahasiswa yang ada di perguruan tinggi dengan siswa di sekolah akan berbeda sesuai dengan kurikulukum masing-masing.

$$
\text { Pentingnya wirausaha bagi }
$$

mahasiswa perlu ditunjukkan dari awal sehingga mahasiswa lulusan dari banyak universitas di Indonesia tidak hanya menggantungkan dirinya pada dunia kerja tetapi mampu menciptakan lapangan pekerjaan. Badan Pusat Statistik (BPS) mencatat jumlah pengangguran sarjana atau lulusan universitas pada Februari 2013 mencapai 360 ribu orang, atau 5,04\% dari total pengangguran yang mencapai 7,17 juta orang. Masalah baru akan muncul ketika seorang lulusan perguruan tinggi masih menjadi pengangguran. Peran dari mahasiswa sebagai pemecah masalah sosial didalam masyarakat menjadi kurang efektif. Lapangan pekerjaan yang sempit dan banyaknya pengangguran dapat diatasi yaitu dengan pembukaan lapangan pekerjaan yang baru. Jika mahasiswa mampu mengambil resiko untuk berwirausaha dengan berbekal kemampuan yang telah dipelajari, mahasiswa akan dapat memecah angka pengangguran dan membuka lapangan pekerjaan baru.

Menurut Wulandari (2013) minat berwirausaha adalah keinginan, ketertarikan, serta kesediaan untuk bekerja keras atau berkemauan keras untuk berusaha secara maksimal dalam memenuhi kebutuhan hidupnya tanpa merasa takut dengan resiko yang akan terjadi, serta berkemauan keras untuk belajar dari kegagalan usahanya. Menurut Aritonang (2008), seseorang dengan minat dalam suatu bidang yang tinggi akan menunjukkan prestasi yang tinggi dalam bidang tersebut. Ketika minat sudah ada maka seseorang akan berusaha untuk menemukan solusi pada hal yang sedang dihadapi. Minat berwirausaha seseorang dapat diukur menggunakan berbagai cara, menurut Sumarwan (2003) hal ini dapat diukur dengan melihat pada struktur pembentukan minat berperilaku yaitu komponen kognitif, komponen afektif, dan komponen konatif.

Menurut Sumarwan (2003), Komponen kognitif terbentuk dari pengetahuan dan informasi yang diterima yang selanjutnya diproses menghasilkan suatu keputusan untuk bertindak. Komponen afektif menyangkut masalah emosional subyektif sosial terhadap suatu obyek secara umum, komponen ini disamakan dengan perasaan yang dimiliki terhadap suatu obyek. Komponen konatif menunjukkan bagaimana perilaku atau kecenderungan berperilaku yang ada dalam diri seseorang berkaitan dengan obyek sikap yang dihadapinya.

Minat wirausaha juga dipengaruhi oleh berbagai faktor karena menurut Wulandari (2013) minat tidak hanya dibawa sejak lahir namun juga tumbuh dan 
berkembang sesuai dengan faktor yang mempengaruhinya. Darpujianto (2010) menyatakan bahwa faktor yang mempengaruhi minat secara garis besar dapat dikelompokkan menjadi faktor intrinsik dan faktor ekstrinsik. Faktor intrinsik adalah faktor yang timbul karena pengaruh dari dalam individu itu sendiri, sedangkan faktor ekstriksik adalah faktor yang mempengaruhi individu karena rangsangan dari luar. Self efficacy adalah faktor intrinsik yang ada dalam setiap individu.

Proses pembelajaran secara langsung ataupun tidak langsung seseorang, akan mengembangkan self efficacy pada dirinya. Self efficacy menurut Bandura (dalam Indarti, 2008) adalah kepercayaan seseorang atas kemampuan dirinya untuk menyelesaikan suatu pekerjaan. Jika seseorang telah memiliki kepercayaan dan keyakinan untuk menyelesaikan tugasnya maka orang ini akan berani untuk mengambil resiko sebagai wirausaha. Self efficacy merupakan faktor yang penting dalam mempengaruhi intensi kewirausahaan (Indarti, 2008). Self efficacy yang tinggi akan membantu sesorang untuk pengambilan keputusan, arah pemikiran yang terarah, kepercayaan diri yang kuat dan siap menghadapi segala resiko yang ada.

Self efficacy juga terdiri dari beberapa dimensi antara lain: magnitude (tingkat kesulitan) mengarah pada tingkat kesulitan tugas, Strength (kekuatan) mengarah pada kemampuan individu, Generality (generalitas) berkaitan dengan perilaku dan kepercayaan individu.

Pentingnya self efficacy menentukan langkah yang akan diambil seseorang karena menurut Indarti (2008) self efficacy akan karir seseorang dapat menjadi faktor penting dalam penentuan apakah minat kewirausahaan seseorang sudah terbentuk pada tahapan awal seseorang memulai karirnya. Tentunya dalam berwirausaha akan banyak tugas dan pekerjaan yang harus diselesaikan, self efficacy berperan dalam hal memberikan keyakinan pada kemampuan individu untuk menyelesaikan tugas dan pekerjaannya.

Resiko mempertaruhkan modal dalam berwirausaha memiliki tingkat kesulitan yang sangat berat. Individu yang berwirausaha harus bisa menentukan sendiri target yang harus dicapainya. Keyakinan untuk dapat mengerjakan semua tugas berwirausaha dengan segala resikonya harus dimiiliki. Self efficacy dapat meningkatkan keyakinan seseorang untuk melewati situasi tersulit yang tidak mementu dalam berwirausaha sehingga mampu mencapai prestasi dalam berwirausaha.

Seorang wirausaha tentu akan memiliki tantangan tugas dan pekerjaan yang sangat bervariasi. Cara pemecahannya juga sangat beragam dan memerlukan langkah kreatif sehingga memunculkan suatu inovasi baru dibidangnya. Menurut Hasan (2013) kreativitas memiliki korelasi terhadap minat berwirausaha. Alma (2011) juga mengatakan bahwa modal utama wirausaha adalah kreativitas, keuletan, dan semangat pantang menyerah. Wirausaha yang kreatif selalu memiliki cara yang berbeda dari kebanyakan orang sehingga seorang wirausaha yang kreatif mampu merubah tantangan menjadi peluang.

Menurut Munandar (2012) kreativitas adalah hasil interaksi antara individu dan lingkungannya. Sering kali orang menafsirkan kreativitas sebagai talenta khusus yang luar biasa. Gaya hidup kreatif dapat terlihat dari cara seseorang mempersepsi dunia, menggunakan seluruh kemampuannya dan mengembangkan kepekaan terhadap masalah lingkungan. Saat individu menggunakan seluruh kemampuannya dan diimbangi dengan kepekaan lingkungan maka akan terjadi suatu proses yang menunjukkan kelancaran, kelenturan, originalitas dan elaboratif sehingga dapat menghasilkan suatu ide atau gagasan yang baru.

Menurut Guilford (dalam Munandar, 2011) bahwa orang-orang kreatif lebih banyak memiliki cara-cara berpikir divergen dimana menggunakan banyak alternatif jawaban dalam pemecahan masalahnya. Tentunya kemampuan ini akan membantu seseorang untuk menjadi seorang wirausaha yang handal. kreativitas dari jiwa wirausaha 
ini akan menghasilkan produk baru, cara yang baru serta berbagai peluang baru. Hal ini juga dikatakan oleh Hadiyati (2011), peran sentral dalam kewirausahaan adalah adanya kemampuan yang kuat untuk menciptakan (to create or to innovate) sesuatu yang baru, misalnya: sebuah organisasi baru, pandangan baru tentang pasar, nilai-nilai corporate baru, prosesproses manufacture yang baru, produkproduk dan jasa-jasa baru, cara-cara baru dalam mengelola sesuatu, cara-cara baru dalam pengambilan keputusan.

Menurut Alma (2011) wirausaha sejati bukan spekulan, tapi seseorang yang memiliki perhitungan cermat, mempertimbangkan segala fakta, informasi dan data. Lebih lanjut lagi, entrepreneur adalah manusia yang kreatif dan inovatif, yang selalu dipenuhi oleh ide-ide baru. Banyak orang berminat untuk berwirausaha namun pertimbangan dan perhitungan resiko yang akan dihadapinya, hal ini cenderung membuat seseorang mengambil posisi aman sehingga tidak berwirausaha.

Seseorang akan berpikir dan mengeluarkan banyak ide-ide dengan segala perhitungannya, namun belum juga memutuskan untuk berwirausaha. Padahal, dalam berwirausaha seseorang akan cenderung menilai rendah kemampuan dirinya jika berhadapan dengan resiko-resiko yang mungkin belum terjadi. Hal tersebut merupakan salah satu penyebab, mengapa angka wirausahawan di Indonesia masih sangat kecil. Jumlah wirausaha Indonesia sampai tahun 2013 masih sekitar 2\% atau 700.000 orang (Ariyanti:2013). Angka tersebut sangat kecil jika dibandingkan dengan jumlah penduduk Indonesia yang sekitar dua ratus juta lebih.

Situasi dan kondisi dalam dunia wirausaha yang tidak menentu dan tidak stabil harus selalu diwaspadai. Perubahasan situasi dan kondisi yang sangat cepat harus diimbangi dengan penentuan keputusan yang cepat pula.

Jika langkah yang telah direncakan gagal maka harus dengan segera mengambil langkah yang baru yang harus diambil.
Dengan demikian, self-efficacy dan kreativitas dalam berwirausaha diperlukan dan berpengaruh dalam proses pengambilan langkah tersebut.

Berangkat dari fenomena di atas, maka peneliti tertarik untuk melakukan penelitian mengenai hubungan antara self efficacy dan kreativitas dengan minat berwirausaha pada mahasiswa program studi psikologi Universitas Negeri Surabaya.

\section{METODE}

Penelitian menggunakan pendekatan kuantitatif dengan metode korelasional. Penelitian ini ditujukan untuk mengetahui hubungan self efficacy dan kreativitas dengan minat berwirausaha

Penelitian ini merupakan penelitian populasi yang menggunakan subjek penelitian mahasiswa yang berjumlah sekitar 445 orang. Populasi adalah wilayah generalisasi yang terdiri atas: objek dan subjek yang mempunyai kausalitas dan karakteristik tertentu yang ditetapkan oleh peneliti untuk dipelajari dan kemudian ditarik kesimpulannya (Sugiyono, 2006).

Subjek penelitian terdiri dari 82 subjek yang berasal dari 4 anggkatan dengan teknik random sampling. Teknik pengumpulan data dilakukan melalui penyebaran kuesioner. Instrumen penelitian menggunakan skala self efficacy yang disusun berdasarkan aspekaspek menurut Bandura, skala kreativitas yang disusun berdasarkan aspek-aspek menurut Munandar, dan skala minat berwirausaha yang disusun berdasarkan aspek-aspek menurut Sumarwan. Analisis data menggunakan analisis korelasi berganda untuk mengetahui hubungan antara ketiga variabel. Analisis data dilakukan dengan bantuan SPSS (statistical product and service solution) 20.0 for windows, dilanjutkan dengan analisis korelasi ganda.

\section{HASIL DAN PEMBAHASAN}

Berdasarkan hasil uji hipotesis pertama dapat dilihat bahwa di antara variabel self 
efficacy dengan minat berwirausaha memiliki koefisien korelasi sebesar 0,703. Nilai signifikansi yang ditunjukkan oleh variabel self efficacy dengan minat berwirausaha adalah 0,000 yang berarti nilainya kurang dari 0,05 sehingga kedua variabel tersebut memiliki hubungan yang signifikan.

Hal ini sesuai dengan penelitian yang dilakukan oleh Wulandari (2013) yang berjudul "Pengaruh Efikasi Diri Terhadap Minat Berwirausaha Pada Siswa Kelas XII di SMK Negeri 1 Surabaya". Subjek dalam penelitiannya adalah siswa kelas XII di SMK Negeri 1 Surabaya. Penelitiannya menyatakan bahwa terdapat hubungan antara self efficacy dengan minat berwirausaha. Koefisien korelasi yang ditemukan dalam penelitian tersebut sebesar 0,658 yang berarti self efficacy dan minat berwirausaha memiliki hubunga yang kuat. Penelitian tersebut juga menyatakan bahwa self efficacy juga berpengaruh secara positif terhadap minat berwirausaha. Jika seseorang sudah yakin terhadap kemampuannya untuk menyelesaikan berbagai macam tugas maka akan mendorong minat seseorang untuk segera memulai suatu wirausaha.

Hubungan antara self efficacy dan minat berwirausaha dapat dijelaskan dari kesamaan dimensi yang ada pada self efficacy dan minat berwirausaha. Individu dengan self efficacy yang tinggi menunjukkan adanya keinginan untuk menyelesikan tugas-tugasnya, memiliki kepercayaan pada kemampuannya, fokus dengan apa yang dilakukannya dan mampu menghadapi resiko (Indarti, 2008). Individu yang memiliki minat berwirausaha yang tinggi juga memiliki kesediaan untuk bekerja keras, memiliki kepercayaan pada kemampuannya, selalu memiliki tendensi perilaku berwirausaha dan siap mempertaruhkan modal yang memiliki resiko (Alma, 2011). Kedua karakteristik ini memiliki kesamaan ciri-ciri dalam penerapannya. Tantangan tugas dalam berwirausaha tentunya akan sangat beragam, namun dengan self efficacy yang tinggi seseorang akan lebih percaya terhadap kemampuannya untuk menyelesaikan tugastugas tersebut.
Selanjutnya, berdasarkan hasil uji hipotesis kedua dapat dilihat bahwa antara variabel kreativitas dengan minat berwirausaha memiliki koefisien korelasi sebesar 0,292. Nilai signifikansi yang ditunjukkan oleh variabel budaya organisasi dengan komitmen organisasi adalah 0,008 yang berarti nilainya kurang dari 0,05 sehingga kedua variabel tersebut memiliki hubungan yang signifikan.

Menurut penelitian yang dilakukan oleh Hasan (2013) dengan judul penelitian "Korelasi Kemampuan Perbaikan dan Perawatan Sepeda Motor dan Kreativitas terhadap Minat Berwirausaha di Bidang Perbengkelan pada Siswa Kelas X Program Teknik Kendaraan Ringan SMK Dian Kirana 1 Sragen Tahun Pelajaran 2011-2012" menyatakan bahwa kreativitas memiliki korelasi positif terhadap minat berwirausaha yang juga menyatakan bahwa semakin tinggi kreativitas seseorang maka akan tinggi juga minat berwirausahanya. Koefisien korelasi antara kreativitas dengan minat berwirausaha yang diperoleh dari penelitian tersebut adalah 0,782 . Perbedaan nilai koefisien korelasi ini dapat terjadi salah satunya karena adanya perbedaan pada populasi dalam penelitian dimana Hasan (2013) menggunakan populasi siswa SMK sedangkan peneliti menggunakan mahasiswa.

Hasan (2013) melakukan penelitian pada siswa SMK yang dilatih keahliannya pada bidang tertentu dan mengukur minat berwirausahanya. Hal ini berbeda pada populasi mahasiswa dimana mahasiswa lebih diarahkan pada suatu bidang profesi yang difokuskan serta lebih memiliki pengembangan karir yang lebih dibandingkan dengan SMK. Banu (2009) menyatakan bahwa sebagian besar lulusan perguruan tinggi lebih siap sebagai pencari kerja bukan pecipta lapangan pekerjaan. Dengan demikian, dapat diasumsikan bahwa siswa SMK dengan kreativitasnya memiliki minat berwirausaha lebih tinggi dibandingkan dengan mahasiswa yang lebih diarahkan untuk profesi yang berkarir di sebuah perusahaan, lembaga, ataupun instansi. 
Hadiyati (2011) menemukan bahwa kreativitas berpengaruh terhadap kewirausahaan. Jadi semakin tinggi tingkat kreativitas individu maka akan mendorong proses kewirausahaan. Kewirausahaan yang dimaksud dalam Hadiyati (2011) adalah individu yang telah melakukan wirausaha. Penelitian tersebut menunjukkan bahwa kreativitas lebih berpengaruh saat individu telah melakukan wirausaha. Tugas-tugas dalam berwirausaha yang sangat beragam akan memerlukan langkah-langkah kreatif dalam pemecahannya, sehingga kreativitas akan lebih berperan. Hal ini dapat disebabkan oleh modal yang telah dipertaruhkan saat memulai wirausaha sehingga individu akan berpikir secara kreatif agar dapat mengembalikan modalnya. Dengan demikian dapat diketahui bahwa kreativitas akan lebih berpengaruh saat individu telah melakukan wirausaha.

Kreativitas juga memiliki arah fokus yang bervariasi (Munandar, 2012). Individu yang memiliki kreativitas tinggi dibidang otomotif belum tentu memiliki kreativitas yang tinggi dibidang lainnya. Kreativitas dalam bidang kewirausahaan dapat ditunjukan melalui inovasi yang dilakukan dalam wirausaha. Kreativitas yang masih terlalu umum dalam penelitian ini menimbulkan nilai koefisien korelasi yang masih tergolong rendah jika dibandingkan dengan penelitian hubungan kreativitas dengan minat berwirausaha yang ada sebelumnya.

Berdasarkan hasil uji korelasi berganda diperoleh koefisien korelasi sebesar 0,757, dan uji signifikansi uji F menunjukkan bahwa Fhitung $(57,2)>$ Ftabel $(3,112)$ yang berarti bahwa ada hubungan yang signifikan antara self efficacy dan kreativitas secara bersamasama dengan minat berwirausaha.

Self efficacy akan membantu seseorang untuk pengambilan keputusan, arah pemikiran yang terarah, kepercayaan diri yang kuat dan siap menghadapi segala resiko yang ada (Indarti, 2008). Kreativitas membantu seseorang untuk berpikir lebih fleksibel, sehingga dapat memberikan caracara dan ide yang baru (Munandar, 2012).
Individu yang memiliki ide yang baru serta siap untuk menghadapi segala resiko yang ada akan lebih bisa untuk mempertaruhkan modalnya dalam berwirausaha sehingga memiliki minat berwirausaha yang besar.

Hubungan dari ketiga variabel tersebut dapat dilihat dari kesamaan antara ketiganya. Self efficacy akan menunjukkan tingkat kepercayaan seseorang untuk berani mengambil tugas dengan beban yang lebih berat. Semakin tinggi self efficacy maka akan lebih berusaha menyelesaikan tugas yang lebih berat. Tingkat kreativitas yang tinggi ditunjukan dengan berusaha untuk menampilkan sesuatu yang baru dan berbeda, tentunya hal ini memiliki tingkat kesulitan yang tinggi. Individu dengan minat berwirausaha yang tinggi akan memiliki tingkat keberanian yang tinggi dalam menanggung resiko untuk mempertaruhkan modal untuk membangun suatu wirausaha. Karakteristik tersebut menunjukkan banyak kesamaan dalam dimensi yang ada pada self efficacy, kreativitas dan minat berwirausaha.

Kreativitas dengan minat berwirausaha menghasilkan koefisien korelasi yang tergolong rendah namun saat dikombinasikan dengan self efficacy menghasilkan koefisien korelasi yang kuat. Skala kreativitas yang masih terlalu umum atau kurang spesifik yang digunakan dalam penelitian ini dapat mempengaruhi nilai koefisien korelasinya. Skala kreativitas dalam bidang wirausaha tentunya akan berbeda dengan kreativitas seperti dalam bidang otomotif, teknik ataupun desain. Hadiyati (2011) menjelaskan kreativitas bagi individu yang telah melakukan kewirausahaan, sehingga fokus dalam penelitiannya mengarah pada kreativitas dalam mengembangkan wirausaha. Individu yang memiliki kreativitas secara umum mengombinasikan dengan kemampuan self efficacy yang dimiliki dan saling melengkapi kompetensi dirinya untuk melakukan suatu pekerjaan. Kombinasi kompetensi ini ternyata memiliki hubungan dengan minat berwirausaha pada mahasiswa walaupun belum tentu mahasiswa akan melakukan kegiatan wirausaha. Dengan demikian dapat diketahui bahwa self efficacy 
dan kreativitas secara bersama-sama memiliki hubungan dengan minat berwirausaha.

\section{SIMPULAN}

Berdasarkan hasil penelitian tersebut, dapat disimpulkan bahwa terdapat hubungan antara self efficacy dengan minat berwirausaha. Hubungan antara self effcacy dan minat berwirausaha terjadi dikarenakan tantangan tugas dalam berwirausaha tentunya akan sangat beragam dan dengan self efficacy yang tinggi individu akan lebih percaya terhadap kemampuannya untuk menyelesaikan tugas-tugas tersebut sehingga individu memiliki minat berwirausaha yang tinggi pula.

Selanjutnya terdapat hubungan antara kreativitas dengan minat berwirausaha. Hubungan antara kreativitas dengan minat berwirausaha rendah disebabkan karena populasi pada penelitian adalah mahasiswa, dimana mahasiswa memiliki kemungkinan pengembangan karir lebih besar dalam bekerja sebagai pegawai dan kreativitas lebih berperan saat telah melakukan wirausaha. Mahasiswa lebih memiliki pengembangan karir di sebuah perusahaan daripada pengembangan kreativitas untuk berwirausaha dan saat melakukan wirausaha orang akan berpikir kreatif untuk dapat mengembalikan modalnya.

Selain itu, terdapat hubungan antara self efficacy dan kreativitas dengan minat berwirausaha. Individu yang memiliki ide yang baru dengan kreativitasnya serta siap untuk menghadapi segala resiko yang ada dan percaya pada kemampuannya dengan self efficacy yang tinggi akan lebih bisa untuk mempertaruhkan modalnya dalam berwirausaha sehingga memiliki minat berwirausaha yang tinggi.

Berdasarkan simpulan yang telah didapatkan, maka dapat dikemukakan saran yang berkaitan dengan hasil penelitian. Adapun saran yang dapat disampaikan adalah sebagai berikut.

1. Penelitian hendaknya memilih tempat penelitian yang banyak terjadi fenomena yang berkaitan ditempat penelitian tersebut seperti pada SMK atau SMA karena mungkin fenomena minat berwirausaha sudah muncul pada usia yang lebih dini.

2. Skala dan definisi minat berwirausaha yang dimaksudkan dalam penelitian masih terlalu umum. Disarankan dalam penelitian minat berwirausaha yang selanjutnya dapat dikhususkan lagi, misalnya minat berwirausaha dalam bidang kuliner atau berwirausaha dalam bidang jasa sehingga hasil dari penelitiannya lebih spesifik.

3. Skala dan definisi kreativitas yang dimaksudkan dalam penelitian masih terlalu umum. Disarankan dalam penelitian kreativitas yang selanjutnya dapat dikhususkan lagi misalnya kreativitas dalam bidang berwirausaha atau kreativitas dalam bidang desain sehingga hasil dari penelitiannya lebih spesifik.

4. Diharapkan penelitian yang selanjutnya dapat memperluas kriteria subyeknya seperti dalam membedakan gender, etnis, ataupun umur agar dapat lebih menggali kecenderungan minat berwirausaha.

\section{Daftar Pustaka}

Alma. B. (2011). Kewirausahaan. Jakarta : Ariyanti, F. (2013). Jumlah Wirausaha RI Alfabeta

Aritonang, K T. (2008). Minat dan Motivasi dalam Meningkatkan Hasil Belajar Siswa. Jurnal Pendidikan Penabur 10 (7) $h \operatorname{lm} 17-25$

Masih Kalah dari Malaysia. http://bisnis.liputan6.com/read/51500 0 /jumlah-wirausaha-ri-masih-kalahdari-malaysia [online] diakses pada Senin 13 Mei 2013 
Azwar, S. (2010). Penyusunan Skala Psikologi. Yogyakarta: Pustaka Belajar

Badan Pusat Statistik. (2013). Laporan Bulanan Data Sosial Ekonomi. http://www.bps.go.id/download_ file/IP_April_2013.pdf [online] diakses pada Minggu 12 Mei 2013

Bank Indonesia. (2012). Laporan Perekonomian Indonesia. http://www.bi.go.id/web/id/Publikasi/ Laporan+Tahunan/Laporan+Perekono mian+Indonesia/LPI_2012.html [online] diakses pada Minggu $12 \mathrm{Mei}$ 2013

Banu, B. (2009). Pengembangan Jiwa Kewirausahaan di Kalangan Dosen dan Mahasiswa. Jurnal Ekonomi Bisnis 14 (2) hlm 100-122

Baron, R. A dan Byrne, D. (2004). Psikologi Sosial, edisi terjemahan. Jakarta : Erlangga

Darpujiyanto. (2010). Pembelajaran yang Menumbuhkan Minat Mahasiswa Berwirausaha. Jurnal Ilmiah Bisnis dan Ekonomi ASIA 5 (1) hlm 22-30

Hadisoegondo, S. (2006). Upaya Penumbuhan Wirausaha Baru: Masalah dan Pendekatannya. Jurnal Infokop Nomor 29 Tahun XXII hlm 49-57

Hadiyati, E. (2011). Kreativitas dan Inovasi Berpengaruh Terhadap Kewirausahaan Usaha Kecil. Jurnal Manajemen dan Kewirausaan 13 (1) hlm 8-15

Hasan, E F. (2013). Korelasi Kemampuan Perbaikan dan Perawatan Sepeda Motor dan Kreativitas terhadap Minat Berwirausaha di Bidang Perbengkelan pada Siswa Kelas X Program Teknik Kendaraan Ringan SMK Dian Kirana 1 Sragen Tahun Pelajaran 2011-2012. Jurnal Teknologi Pendidikan 1 (2) hlm 214-225

Henri, S S. (2013). Jumlah Wirausaha Turun Drastis.http://www.metrotvnews.com /metronews/read/2013/05/07/2/15194
3/Jumlah Wirausaha-Turun-Drastis [online] diakses pada Kamis 20 Juni 2013

Indarti, N. (2008). Intensi Kewirausahaan Mahasiswa: Studi Perbandingan Antara Indonesia, Jepang dan Norwegia. Jurnal Ekonomi dan Bisnis Indonesia 23 (4) hlm 1-27

Jumlah Penduduk Indonesia. (2013). www.google.com/publicdata [online] diakses pada Kamis 11 Juli 2013

Lukmayanti, A. (2012). Hubungan Efikasi Diri dengan Minat Berwirausaha Siswa Kelas XII Program Keahlian Jasa Boga di SMK Negeri 6 Yogyakarta. [Skripsi]. Yogyakarta : Universitas Negeri Yogyakarta

Mawardi, D. (2010). Belajar Goblok dari Bob Sadino : Tanpa Tujuan, Tanpa Rencana, Tanpa Harapan. Jakarta. Kintamani

Mujiadi. (2003). Psikologi Perkembangan. Yogyakarta: Gadjah Mada University Press

Munandar, U. (2012). Pengembangan Kreativitas Anak Berbakat. Jakarta. Rineka Cipta

Murwani, A. (2013). Faktor Penentu Minat Berwirausaha di Kalangan Mahasiswa Perguruan Tinggi Negeri : Studi Perbandingan Mahasiswa USU, UNIMED dan IAIN. Jurnal Keuangan dan Bisnis 5 (1) hlm 15-29

Pamungkas, S. (2007). Minat Berwiraswasta pada Mahasiswa ditinjau dari Konsep Diri dan Motivasi Berprestasi. [Sripsi]. Semarang : Universitas Katolik Soegijapranata

Puri, Y S. (2013). Hubungan Antara Adversity Quotient dengan Minat Berwirausaha Siswa Kelas XII Pemasaran di SMKN 1 Surabaya. Jurnal Pendidikan Tata Niaga 1 (1) hlm 1-20

Robbins. (2007). Perilaku Organisasi: Konsep, Kontroversi dan Aplikasi. Jiilid 1. Jakarta: Prenhallindo.

Rumawouw, G J. (2010). Praktek Wirausaha Bagi Mahasiswa dalam Meningkatkan 
Ekonomi. Aptekindo hlm 563-576

Santoso. (1993). Kompetisi dan

Kepercayaan Diri Remaja.

Yogyakarta: Liberty

Sekertariat Dewan Nasional Kawasan Ekonomi Khusus. (2011). Ekonomi Indonesia.

http://kek.ekon.go.id/index.php/in/ten tang-indonesia/ekonomi.html [online] diakses pada Minggu 12 Mei 2013

Sekertariat Kabinet Repulik Indonesia. (2013). Survei BI: Masyarakat Optimistis Terhadap Kondisi Ekonomi Saat Ini. http://setkab.go.id/berita-7952-surveibi-masyarakat-optimistis-terhadapkondisi-ekonomi-saat-ini.html [online] diakses pada Minggu $12 \mathrm{Mei}$ 2013

Sugiyono. (2006). Metode Penelitian Pendidikan, Pendekatan Kuantitaif, Kualitatif dan $R \& D$. Bandung: Penerbit Alfabeta.

Sumarwan, U. (2003). Perilaku Konsumen Teori dan Penerapannya dalam
Pemasaran. Bogor: PT. Ghalia Indonesia.

Suryana. (2006). Kewirausahaan. Jakarta: Salemba Empat

Universitas Gajah Mada. (2011). UGM Cetak Lulusan Siap Kerja. http://www.ugm.ac.id/index.php?page $=$ head line $\&$ artikel $=351 \quad$ [online] diakses pada Minggu 12 Mei 2013

Wulandari, S. (2013). Pengaruh Efikasi Diri Terhadap Minat Berwirausaha pada Siswa Kelas XII di SMK Negeri 1 Surabaya. Jurnal Pendidikan Tata Niaga 1 (1) hlm 1-20

Yudha, W (2013). 360 Ribu Sarjana Jadi Pengangguran.

http://news.okezone.com/read/2013/0 5/29/337/814724/360-ribu-sarjanajadi-pengangguran [online] diakses pada Kamis 30 Mei 2013

Yudhistira. (2011). Berhentilah Sekolah Sebelum Terlambat. http://edukasi.kompas.com/read/2011/ $04 / 08 / 10450289 /$ [online] diakses pada Minggu 12 Mei 2013 